This article was downloaded by: [University of Toronto Libraries]

On: 23 November 2014, At: 17: 10

Publisher: Routledge

Informa Ltd Registered in England and Wales Registered Number: 1072954 Registered office: Mortimer House, 37-41 Mortimer Street, London WIT 3J H, UK

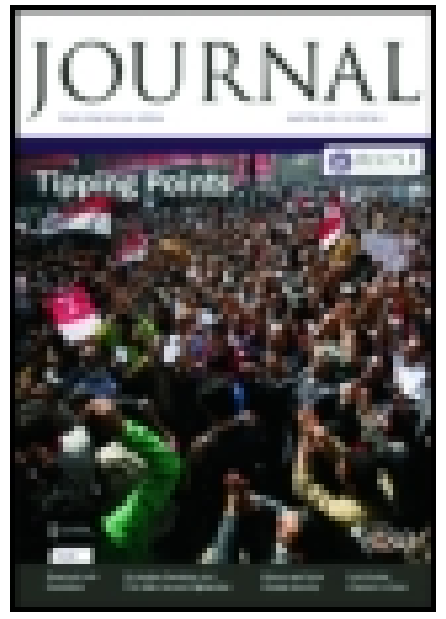

Royal United Services Institution. J ournal

Publication details, including instructions for authors and subscription information: http:// www. tandfonline.com/ loi/rusi 19

\title{
The Strategical
} Conditions of our Indian North-West Frontier

Major-General E. B. Hamley C.B., R.A.

Published online: 11 Sep 2009.

To cite this article: Major-General E. B. Hamley C.B., R. A. (1878) The Strategical Conditions of our Indian North-West Frontier, Royal United Services Institution. J ournal, 22:98, 1027-1046, DOI: $10.1080 / 03071847809416663$

To link to this article: http:/ /

dx. doi.org/ 10.1080/03071847809416663

Taylor \& Francis makes every effort to ensure the accuracy of all the information (the "Content") contained in the publications on our platform. However, Taylor \& Francis, 
our agents, and our licensors make no representations or warranties whatsoever as to the accuracy, completeness, or suitability for any purpose of the Content. Any opinions and views expressed in this publication are the opinions and views of the authors, and are not the views of or endorsed by Taylor \& Francis. The accuracy of the Content should not be relied upon and should be independently verified with primary sources of information. Taylor and Francis shall not be liable for any losses, actions, claims, proceedings, demands, costs, expenses, damages, and \pm other liabilities whatsoever or howsoever caused arising directly or indirectly in connection with, in relation to or arising out of the use of the Content.

This article may be used for research, teaching, and private study purposes. Any substantial or systematic reproduction, redistribution, reselling, loan, sub-licensing, systematic supply, or distribution in any form to anyone is expressly forbidden. Terms \& Conditions of access and use can be found at http://www.tandfonline.com/page/termsand-conditions 


\section{LECTURR.}

Friday, Deccmber 13th, 1878.

Mijor-Generic Sir HENRY C. RATVLINSON, K.C.B \&c.j \&c., in the Chair.

\section{THE STRATEGICAI CONDITIONS OF OUR INDIAY TVEST FRONTIER.}

By Major-General E. B. HaMLer, C.B., R.A.

I APPEAl here, in compliance with the desire of the Cor offer some remarks on our Indian frontier. I should not hav to volunteer to do so, and I do it, I will not say with for I am happy to comply with any wish of the Comr certainly not without misgiving, feeling that among you certainly some, perhaps many, Irdian officials of the highe tion. Jitt $\mathrm{I}$ am oncouraged by the thought that a personal ance with a territory is not indispensable to the formation $c$ cal opinions about it-if it were, the majority of the $\mathrm{me}$ campaigns would never have been planned. I am encourdig fecling how little aid the subject requires from me to re teresting-nerer has the interest it has excited been so strc thongh for nearly thirty years it has been warmly discussed ininds in India. These still contest each other's conclus widely divergent points of view, and I may therefore perha it a point in $\mathrm{my}$ farour that $I$ have appronched the subje bias, is I would any other strategical problem, desirous only at a right conclusion, and uninfluenced by the rcight of opi one side or the other.

First, let us look to the Indus-often spoken of as $t$ frontier of India. To be a good line of defence a river, be difficult to cross, should have protected bridges in the po. tho defender, connected by good communications oin the baink, and thit bank should, at important points, commaind The Indus is unbridged by any permanent structure. In half it is a swift, even turbulent, stream flowing mostly rocky bed--from 100 to 400 yards wide-in its lower, $t$ swift, it flows betreen flat banks and frequently changes -insomuch that the bridge of one jear might be left on । 
the next. When the snows melt the river rises and spreac over its banks - thus bridges would at times be swept awa merged, and roads along the bank would be useless. T] bridge of boats at Attock which has been frequently carried a another was thrown two years ago at Khooshalghur. Nev I believe that permanent bridges might be thrown-it is question of expense. The left bank is flat throughout an quently conmanded by the right. These are circumstanc taken into account when we are told that the Indus is tl frontier of India.

Beyond the river, at an arerage distance of some fifty $\mathrm{m}$ the frontier line, which let tus define for the present purpose on the right by a point opposite the Khyber, on the left by site the Bolan. The distance measured along the river in re line from $\Lambda$ ttock to Sukkur is about 500 miles, the fronti course being considerably longer. This frontier runs for gre its length along the foot of a mountain range, penetrated bet Bolan and the Khyber only by a few difficult passes. N barriers, that which gives most security, next perhaps $t_{1}$ desert, is a range of this kind, and hence a few thousan prevent the depredations of the hill tribes, suffice to protect of frontier which, were it of a different kind, with a powert bour on the other side, would demand, in case of a formidable armies, and even in peace very considerable forces, for its There are several passes between the two I have named, br the Khyber, it will only be necessary to speak of two in thi the frontier, the Knrrum, issuing in our territory at Thull aI and the Gomal, issuing opposite Dera Ismail Khan. Othes there is one that issues in the bed of the Kurrum rirer nea but besides that we know little of them, except that they ar ingly difficult, there is another reason why I should not or time in describing any south of the Gomal.

There will be no dispute that the Khyber is, of these 1 fittest for the passage of a column of all arms. It is $]$ shortest, the easiest, the best supplied with water, and directly the most important points, namely, the city of Cauk favourable place for bridging the Indus at Attock, whenc great road, to Lahore, and thence into the valley of the Gan:

of the Kurrum we have learnt a good deal. It is easy o all the way from the Indus to the Paiwar Pass, but from the point where it joins the hill road between Caubul and $\mathrm{Gb}$ Kushi, it is of exceeding difficulty, impassable for any kind c and rendering the supply of even a lightly equipped cc arduous task. Whether General Roberts had at first any $v$ his train I do not know. It is to be inferred that he had the fact that his light guns were carried on mules, hi artillery on the backs of elephants-howerer this may be, $r$ certain he has none now. The issue of this pass in our tc

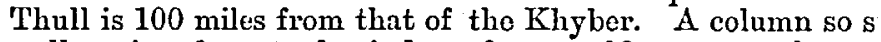
well equipped as to bo independent could not pass here; 
could not act independently would scarcely venture; and likel 5 , therefore, that any serious attack will be made by w Kurrum, or of that other pass which issues near it.

The Gomal, from Ghuznee, does not present the insuperable । of the Kurrum, and conld be made practicable, though not c colnmn of all arms; at the best it would still present m broken extent of track, and many narrow passes. It is cuitons, and about a third longer than the Khyber, from r distant 200 miles.

In forming an idea of a march in force through such pass assist us to romomber that an English Army Corps, say 24, ( with artillery, extends with its combatant forces only, on a road about 16 miles in length, and with its trains 27 miles. only a slight increase for the nature of the road, the comb: similar force in the pass would stretch 18 miles, the total v 30. Thus, when the head of tho combatant column issued pass, its rear would be nearly two days' march behind; and c the host of animals required for the necessary supplies on s pedition, the rear of the trains could then scarcely bo les days behind the head of the column, that is to say, only marches beyond Jellalabad.

Accustomed as we are to see the mountain chains of Euror fully passed by great armies, we must be careful to reme: different in depth are thoso ranges from the hills of Afghan a couple of marches the Prussian armies were through the mountains, and presently combined in the attack at Sade here, the shortest pass through the barrier, that between $\mathrm{C}$ the Indus Valley, is 190 miles long - the Gomal nearly $300 \mathrm{r}$ not days but weeks are occupied in the isolated march.

Now, when we remember what an invading army of India that it shall bear with it the means of passing the Indus-tl be prepared to encounter the forces of our Indian Impirethus formidable in numbers and equipment, it must rely $f_{c}$ on the path through which it has issued, we shall form of the difficulties which would encompass an army in its : enter India by these routes; and these difficulties I will a bear in mind when I recur to this part of the subject. Let ? what conditions another part of the theatre may present. I me pause to say what I understand by an invading army. ] assembled forces of the Afghans-not such a Russian force lately assembling on the frontier of Bokhara-not such $\varepsilon$ Persia can at present send forth-any or all of theso wou short of the requirements of such an enterprise. But I w that Russia has completed those improvements in her comm. which we know she persistently contemplates; that she has Caspian and the Aral by a railway; or that, combining w she has made a convenient way from the southern shore of $t$ to Herat; that the ruler of Afghanistan has thrown in $h$ them; and that within the fortified triangle Herat, Caubul, the dispositions for this great undertaking have ber 
deliberately, with all the aids of military science, to complet may be assured that an inrading arny of India, such as ? nfford to despise, will be no improvised force, no barbarous 1 truly formidable in numbers, organization, and leadership will further assume for the moment that, as has been so oft mended, Te await the attack in the ralley of the Indus.

From Canbul the confederated forces of the enemy, posted suggested, will threaten an advance through the western pas Kandahar they will threaten an advance throngh the Bolan follow the morements of what we may call the enemy's Arı Bolan, assembled abont Kandahar. As it moves south it wil character of the country very different from that of the districts of the north. The hills are no loiger of impenetrab mancourring ground exists alnost everywhere; a great pa country consists of extensive plains; and though there are a $\mathrm{ft}$ formidable if lield, yet they are by no means such obstacles of the Suleimnn range. Orer one of these, the Khojak, passes to Quetta. From thence tho main road, and thi used by caravans travelling to the Indus valley; is thri Bolan Pass to Dadur. There is another excellent road $t$ From Khelat there are two ways into this portion of the Ind one direct but difficult, the other circuitons but practice leading on Gundava. But the best road, one that with a lit might be called good, is that through tho Bolan; the length pass is 59 miles.

But when I speak of these roads issuing in the valley of $t$ I must indicate the circumstances under which they enter imountain barricr which has continued to define our frontici point in adrance of Mrittree on the Indus, there turns west the frontier of Khelat for a considerable distance, when it $\mathrm{rr}$ southerly direction. It follows that the right bank of the $I_{1}$ about Mittree to far below Larkliana is an immense plain. passing along the river there, see the horizon extending like t ocean. Into this great plain the Army of the Bolan would hundred miles from our frontier, and, while halting to conci lengthened columns, and to fortify tho passes in its rear, it before it $a$ space of the valley of at least 150 miles in widi part of which to direct its attack; and having formed its pla I am told on the best anthority, adrance in the dry season nee where across this plain on a wide formation and accompanied all its trains and baggage. Regular routes lead from Gun Larkhana, while Dadur, besides being in direct communic: Gundava, is the place whence most of the roads direrge points in the specified portion of the Indus valley.

Now, though this plain is poor, and though it requires a perienced management to obtain a good supply of iwater : would put it to you whether such an inrading army a imagined could reasonably hope for more farourable circ in which to enter a theatro of war than those in which it $r$ find itself. 
Painsing for a moment here, let is look back to the other si theatre, and suppose that ain army is also moving from Canb Indis ralley. We krow that it will adrance in long processios down the Gomal or the Khyber Passes-that it will issue through narrow gaps, into the presence of the defender's troo it will have, or onglit to have, to fight with the heads of its oven for the power of making its first deployments, and $t]$ deployed the greater pait of the army will haro at its $b$ practicable lines of supply; or of retrent, but inipassable mi It will not be contested that this is a very different situation $f$ of the Bolar Atriny-in the one case we lave ait aimy issuin. form of columns, closo to the enemy-in the other an army ing on a full front with the enemy still at a distance. I therefore; that however the enems mas think it proper to di by feints or diversions leve, the minin line of advance will $b$ Lower Indus.

Next, as to how we should meet the invasion: The port o chee is a point where troops and stores fromi England, $f$ Mediterraneain stations, from Bombay; can easily and con concentrate. It is also the terminus of the Indus Valley which; if not actually completed, is so near completion th: take it as an accomplished fact. Br rail, and also by the riv gable for large steamers to befond Sulkur, the readiest mean concentrating from home aidd elsewhere, as indicated, upoin $t]$ Indus. From Lahore, by Mooltan, the same part of the Indus i: by rail-the communication across thic river being by st And from Liahore also a railmay now extending to, or beyond and which will shortly reach the Indus, affords a ready 1 reinforcing Peshawur. This Indus Valley railway is not to be by the capacities of our English railways. It is only a six buris irood for fuel, and maintains but a moderite rate , But, as it is, it is irvaltrable; it enables the Bengal troops to casily with those of Bombay, and it gires great facility forcing eitlicr extremity of our frontier line. The Quetta has already profited by it; hating been convejed by $r$ Mooltan to a station opposite Mithiun Kote; and all trot Bombay or Karracheo will also experience its benefits: a more momentons crisis than the present, snch a one a been supposing to exist, we should bring our whole bear in this part of the theatre. In fact, there is, I think in the world where we could make such a military di strength at short notice as on the Lower Indus. Thus, passes suitably guarded, the Army of the Lower Indus bled beyond the river, the reserves at Lahore and Mooltan reinforce either of our tro Armies, we shonld be in a situa of promise, and it was the consideration of it which cause express elsewhere the opinion that we ought, with good man: to give an excellent accoint of any foe who should attack. ralley of the Indus:

But good grounds as there are for taking that riew on of 
have also just endeavoured to show that the enemy's Arn Bolan would meet us here under the most favourable circr that it conld possibly hope for-its rear secured, its front advance easy, and with a wide space of our frontier npon direct its operations. Moreover, it is to be observed that th so invalnable as our line of commanication, and protect upper portion by the river, runs from Sukkur to Kurrach right bank, and that we conld scarcely hope, before having decisive action, to guard it against the enemy's enterprises out the wide extent on which they would menace it. I w fore, now pass to the consideration of whether we shall not: cnemy to much better advantage on a more advanced line.

The argument which is always pat forward in support of of remaining on the defensive is, that we should thus await resources an enemy who would have advanced to a grea from his. The argument thus stated would imply that it judicious to arait invasion. But this is manifestly not tr! majority of brilliant campaigns have been those of invasion. times a judicious course, sometimes not. It is judicious whe by the weaker nation, deficient in the money, material, and tion which an offensive campaign implies, and at the same sessing a frontier and a conntry topographically strong. B tainly should not like to consider ourselves as likely to be $t$ party, either in resources or in organization, in the contest I templated. Again, a defensive war will often combine the otherwise discordant empire in a patriotic nnion against th enemy. But it is, I believe, the concurrent testimony of al that there is no territory on which it could be more perilo an enemy the chance of winning a battle than our Indian $\mathbf{E}$

Let us look, then, towards a more advanced line; and her is much simplified by the fact that we have already occupi By doing so, it is we who are in the position of commanding into the enemy's country, and of securing the passes in while we have the further inestimable advantage of havin the back of the mountain district-that is to say, of holdin of the frontier, and of seeing before ns a country, not of cc out its difficulties, but offering at the same time immensely facilities for skilled operations. Wo are thns, too, carryir our theatre of war out of our own territory, which we co advance. And for communications, besides those before e1 the construction of the branch railway from the Indus already designed and officially talked of as intended, wil great degree the distance of Quetta from the frontier and $x$ difficulties attending the march.

Looking next at the avenues out of Quetta, we find the $h$ : Kandahar, which offers no difficulty to the march of as except the Khojak Pass, the nature of which as an obst believe, been greatly exaggerated. Another road to the left also over the Khojak range; and there is still another mas side of tho desert. But, though our troops, in former 
frequently marched through that country, being in small bodies they moved only on one road, and we know nothing from actual observation of the two I have mentioned. There is another road which, branching north-east from the Kandahar road, a little ray ont of Quetta, traverses the hill country, and this, though very rugged, wo know can be nsed by troops of all arms, for the Bombay division moved by it in the former war from Ghuznee npon Quetta. And what I would specially call attention to, lest you should think I had dismissed the subject of the passes too briefly, is that by occapying Quetta we practically close all passes to the Indus Valley which issue south of Dera Ismail Khan.

Strategically, then, I lope there remains no doubt of the immense adrantage of holding Quetta, whether as a means of controlling Afghanistan or of meeting such a formidable combination of enemies as I bave contemplated. Proceeding to inquire what tactical features it may offer, it appears that, on passing the Bolan, the road goes for some twelve miles over a waterless plain, before entering the cultivated district, also a plain, which surrounds the town. Quetta stands round an isolated conical hill which commands the plain behind it, but is itself commanded by high ground in its front. It became, therefore, of importance to know how this might be remedied: and I am informed by the very capable Officer who survesed the district, that a mile or two in front of the town, and within Khelat territory, there is an excellent position, far out of reach of any other commanding ground, and dominating the valley beyond. This seems to be confirmed by a late telegram from there, which mentions an additional fort just constructed as having rendered Quetta quite impregnable. On the left of Quetta, between it and the desert, the line of hills is only passable at a single gap; and a similar range, not passable at all, exists on the right. Tactically, then, as well as strategically, for defence, as well as offence, against either a powerful or an inferior enemy, it would appear alike adrantageous; and while tho policy of taking possession of it has for many years been powerfully opposed, and while the measure was carried into effect almost unnoticed in this country, it appears, if the adrantages are such as $I$ have stated, that we hare here the most valuable possession on which England has laid her hand for many a day.

Having got so far, however, the question is not jet settled of whether we hare jet reached our most advantageous frontier. I have considered the confederated forces as within the triangle Herat, Caubul, Kandahar-tho richest, most open, and most temperate portion of Afghanistan : and if they meant to attack us, whether in the valley of the Indus, or at Quetta, their position would be strong, and strong also against attack. Caubul would, so long as thoy might hold it, threaten Peshawur-and Kandahar would form a strong point of concentration for an advance. And the hostile Army so placed might, without imprudence, send an advanced force to occupy the Khojak Pass, tho only very difficult or specially defensible part of the road between Quetta and Kandahar, about 90 miles from Kandahar, 60 from. 
Quetta, thus acquiring the option of receiving battlo the caso of its advance, the gaining of so much ground.

I will go on, then, to suppose that the result of our pres tions is to gire us the power, if we choose to use it, of Kandahar, with a small space beyond it, necessary to complete gical value. The obstacle of the Khojak would thus disal Kandahar, the richest district of Afghnnistan lies before ns practicable roads lead from thence on Ghuznee and Can one side, on Herat on the othor-and others lead from it Helmund to the Persian fronticr and thence on Meshed, $i$ of Herat. The space bejond should therefore include a the Helmund river, with the command of the passago a Of the communications with Quetta I have already spoken.

It is to bo noted that between Herat and Caubul, two of cities which I have supposed the enemy to occupy, lies th the Hazaireh mountains, the road through which, between tl is so bad that the circuit by Kandahar, or by a route no mountains, is generally preferred. Hence another import: quence would follow from our occupation of Kandahar, $\mathbf{n}$ : rupture of the enemy's front; for if he occupied Caubul we co the forces thero from those at Herat-if ho did not, we shol to bring our whole strength to benr on the side of Herat. dahar, too, we should hold such a position towards Persia scriously affect her relations with Russin; and tinally, or there would be almost decisive against any design of the invade India through the passes. Observe, I do not say occupy Kandahar, by friendly treaty, as we now occupy $\mathbf{Q u}^{\prime}$

I think it is impossible to deny that our Army posted delightful climate, and with snch strategical possibilities could desire no better field in which to contest with Russi allies the Empire of India. And perhaps many of you with mo that the leader of that Army will be, in his opport most fortunate British soldier whom we have seen since TVe

Resting here, it becomes necessary to look at tho other: strategical theatre, and to consider the question of an advo frontier-line from the Indus valley in that quarter also.

The road from the eastern issue of the Khyber to Canbul by two chief difficulties. With those of the Khurd Khyk sufficiently familiar. Issuing from it a more open regio itself, extending beyond Jellabadad.

The iden that some advance of our frontier might bo ex] como to be generally contemplated; this is tantamount in $\mathrm{n}$ to considering that any step forward must be advantageou step that finds favour is that of pushing the frontier forws side to Jellalabad. One reason assigned for this is that wes command the ralley which ascends from behind Jellalabad This point would never, I confess, have occurred to me been indicated elsewhere; it seems to imply that we may Russinns that way. But what does such an expectation. means that Russia, after pushing her forces to the sou 
Oxus-after forming a secondary base or fresh starting po platea of Pamir-after crossing the Hindu Kush-is 250 miles down this rallog, and for what? If she desires either Caubul or the Kliyber, surely she will possess herself direct and conrenient route to those places. If she does, this? If she does not, is it to bo supposed that she will ent an enterprise by such a line? But it will be seen that the c. provided for in a general plan, and I will pass to the otl that has been assigned, namely, that wo should thus havo st passago of the Khyber. Now, the permanent occupation c bejond that pass must have either a defensive or offensi First, as to the defensive. If a point in advance of tho $\mathrm{Kh}$ the knot where a number of roads united which led from $t$ ] the Indus Valley, the policy of occupying it would be obvi it covers nothing, and commands nothing, but tho pass itself. difficulty of supply by such a road would prevent a very li from being permanently posted there. On the other hanc nothing to prevent a powerful enemy who may possess Ca1 bringing any force he pleases to attack the permanent post $i$ of the Khyber, which must then be reinforeed if possible rear. Nor would the difificulty bo remedied-on the contrary -if our defensive post were pushed further, through the pa: to the Canbul ralley; a measuro which, I believe, nobody has to propose. On the other hand, if the reason for proposing 1 such a position is that we should thus have nceomplishs towards obtaining entrance into the district bejond the $\mathrm{r}$ in an offensive campaign, we must remember that betweer trict and Jellalnbad thero are many difficnlt marches and at most formidable pass. None but a strong and well-equipF in fact an Army, could venture thus to menaco such a fort such support beyond it, as Caubul would present under th stances I have imagined.

Now it is to be noted that an Army here rould be from an Army on the Lower Indns by at least 500 miles-fr Quetta by at least 700 miles-from one at Kandahar by $\varepsilon$ The British armies would, therefore, be under separate comm operating with distinet objects; nor could they combine excep: portant successes gained within the enemy's territory. The ene] other hand, would possess the advantage of operating from : centre against widely separated bodies advancing towards th In fact, considering the difficulties of supplying this Khyber . should bo voluntarily adopting, in its worst form, the double nll its disadvantnges, and without the excuse of necessity, could throw our whole weight with full advantage on the 0 I think, therefore, there is much to be said against, nothin occupation of a post beyond the Kliyber, and that it would be not of strength but of weakness.

In saying what I think should not be done, I am prepar what I think shonld be done on this side; and it is tory to mo to think that the alternative plan, while, in $\dot{m}_{\mathrm{J}}$ 
tho best in the military sense, involves no extension of no expenditure worth mention, and no increase of frontier 1 consists, first, in blocking the mouths of the Khyber on our with an intrenched camp armed with powerful artillery, to bo $g$ by the Pcshawur troops, reinforced in case of need. If suitably occupied, I cannot conceive how an enemy's for ever superior, advancing, as it must of necessity, in les even straggling, array to the mouth of the Khyber, could ex to issue from it. It seems to bo one of those cases wher ress, often so doubtful an expedient, would be absolutely By fortress I mean those lines of works about a central w combination of fortress and camp, affording space for the $\mathbf{m}$ of its garrison, which modern engineering science consider. kind of stronglold. And to view the matter by the light parison, let us suppose an attempt to secure the other er froutier, in Sind, with its 150 miles of flat front, by means of 1 It is evident that in that quarter a single fortress would nol a system of fortresses would be needed, such as would sv an army. But in front of the Klyber a very moderate single line of works would answer the purpose.

In like manner, an intrenched camp armed with heavy might be placed at the issue of the Gomal Pass and ocenpi garrison of Dera Ismail Khnn; and another, though rather to s the fecling of security than from necessity, in front of the B

To complete the system of defence, these posts should has rear protected passages over the Indus, connected with the r branch lines.

It is necessary to notice the plan of sending troops up thi passes and occupying the crests by way of advancing our Now I scarcely think that those who propose it have consid it would be to maintain permanent posts on those incleme with only such lines of communicntion and supply behind th rallers afford. And considering them as a preparation for $\mathrm{s}$ operations in a campaign, we should, in using these pass adrance, be operating not by double but by quadruple or lines of operations. Surely it would be nothing short of thus to fritter away our strength when wo can mite our for a single leader, on the side of Quetta or Kandahar.

To leave no alternative untouched, I will now suppose tha pushed through all the passes, made the mountain territory placed our posts on the road from Canbul to Kandahar. I sider for a moment how an extensive frontier is generally The line of communication between the posts should pass no but behind their front. Any of them when driven back sh secure lines by which to find support from others, and retiring should possess, in numerous roads, the means of con upon important points. But what of this do we see in our new frontier? There wo have bodies widely apart, isolated $k$ advance of the encmy, each with its own narrow pass to rel entering which it continues to be isolated from the others 
till it emerges, still at a great distance from them, in our $r$ ritory. I-trust we shall not ineur the charge of such a vas barren territory, with its sarage populations, for such $\varepsilon$ this, and that onr notion of a rectified frontier will not ir of these isolated lines and posts thas nnmeaningly thrast fo the monntains. Any good that could possibly be hoped them would be much more effectually accomplished by tl Kandahar.

Apart from the question of a more formidable foe, it ap believed that these posts pushed up the passes would chances of future contests with the unruly hill-tribes. Th: unruly would appear an excellent reason for kecping them i: wither than in our rear. Posts separated by such distance inaccessible country, can exercise no influence on the inha tween; on the contrary we should thus be offering then potent means of molesting us. I fear that slenderly-escort. would offer irresistible temptations to the half-starved Such a measure then, in time of war most mischierons, as in chances of disaster, would be in time of peace antly and bu for it would not in the least obviate the necessity of keep present line of frontier guards.

When, in the former war, our forces mored on Kandahar of the south were no less hostile and mischierous to as thi the north, and every march from the Bolan to the $\mathrm{K}$ marked by their depredations on our trains, bo the slaugh conductors, by the murder of stray soldiers and numbers less camp followers. But a few years afterwards they we thoroughly peaceable and friendly by vigorous landling an management. At least one most distinguished Officer w leading part in the process still lives to tell us what the $p$ It might be worth trying on other parts of the frontier; he may be, the result for us, and one well worth taking into that, to all appearance, our trains march as safely now from to the Khojak as from London to Aldershot.

The plan, then, to which I arrive at the end of this train of has at least the merit of simplicity. The camps in front of become the fixed pirot of operations : the main forces, assem first instance where they can most easily assemble, that is the Lower Indus, are the active army. As I have said, I confident of the result eren in the valley of the Indus; : position rastly improred by the occupation of Quetta; $b$ think it all we could desire if we occupied Kandahar. ever of these two points we select for the adranced post of must be made the site of an intrenched camp powerfully railway to Dadur must be made, and the roads between camp everywhere improved.

There is one case in which the garrison of the camp wa Khyber might cease to be merely a defensive force. If, in of the campaign, as is likely, the Kandahar Army or part c roL. XXII. 
invest Canbul, the troops might come though the Khyber the siege and probably in subsequent operations.

Thus, then, I have endearoured to sketch a definite $I$ which to concentrate our resources, and by which to secure a frontier, and a permanent settlement of this large question. at the northern half of this part of our territory, I think $r$ be thankful for possessing a frontier so easily rendered imF Looking at the southern half, we have no less reason to be for having acquired, in Quetta, such means of vigorous ani action, and such an opportunity of securing new adranteges of important and decisive kind. With a garrison strongly posi lines at Kandahar, with all the routes and stages by which. might be assembled on that point, all sonrecs of supply arrangements for transport, laid down, as our trained Staff $O$ certainly capable of laying them dorn, we might vier ca possib!e complications before us, whether arising from the ar military porrer of Russia in the East, from the success of her or from her open lostility. The grounds of our assurance manifest and easily understood, our native subjects would s to appreciate them, and what would be security for us woulc quillity for India.

MInjor-General Sir Frederic Goldsurd : Hnving been myself on $t w$ ono connected with Persia and Beloochistan, and another with Persin a istan, I know much of the western frontier of the latter country from scrration. As regards the eastern fronticr of Afghanistan, my acquai the subject is strengthened by long residence among Afghans, Bcloochis, of the countries in the immediate neighbourhood, especially in Upper Kurrachee. I have, moreorer, long felt very great interest in the ques. Indian fronticrs in the north-west, and have made it, more or less, a study. therefore, and some other claims, howerer small, to express an opin subjest, I renture to state my thorough conviction that what General ] proposed is exnetly what we ought to do. I do not, indeed, know of a sing that can be raised against his scheme, which has been so clearly put forr could hardly fail to be intelligible to all hearers. One very important a holding Candahar is that by so doing, we really hold the main line of com between Cabul and Herat. There may be another ronte to the north of tl: chain, by Ifaimana; but it is rather roundabout, and probably not so frequented as tlat by Farmh, Candahar, and Ghuani. The road betreen Cabul by the Irazareh country is passable, and I beliero troops hare pro way. I hare been looking only this morning at Conolly on the subjec examined it by the light of maps. It is haydly, in my opinion, a di From Herat its course is apparently to the south-cast; it then turns up a going to Bokhara, and then inclines towards Cabul, and joins the road , from that city to Bamian at a place called Gardan-i-Divar. But I do that that road need really be taken into account, because it is a rery difl not only phrsically difficult, but difficult on account of the nature of through whose country it passes. There are, for instnnce, two sets of In Sunni and the shia dirisions. 'To conciliate the one would not necessi concilinte the other.

Lord Warexer: Those who have read the debate which has just taken ] House of Lords will remember an exceedingly happy illustration, giren $b$ Chancellor, of the topographical circumstances of Afghanistan, in whicl his parallel from Scotland. He requested his audience to consider that before them a large mass of mountains, such as the Highlands of Scotland I derire from that illustration an opportunity of observing horr old mat1 


\section{OUR FNDIN NORTI-WEST FLONTLER.}

themselres, and how, when the new is ingroored into the old, under the c stances which hare been presented by our lecturer, we may infer, from $\mathrm{pr}$ success, a success for the plan which he has proposed. Now it will be observ those who are familiar with the circumstanees of the mass of mountains of Sc that those mountains were inhabited, in the old times, by tribes answering in the: like character, as distinguislscd from those inhabiting the low lands, to the mo tribes of Afghanistan, as distinguished from the dwellers by the Indus; and be recollected, that one of the great difficulties of the English Fings in the ation process going on, was to deal with these tribes; and practically Ed. and his successors adopted the same principle for the permanent and su mode of disposing of the disturbing force from the mountains as is sug at the present moment by General Famley, in closing the passes. It it obserred by those who hare trarelled on the scaboard and the inland estuaries and rivers of Scotland that, at all points where a débouché from th might gire opportmity for the northern clans to pour into the low lands, the be found a castle, not of ancient sea rorers, but a castle of the Norman n system. These castles sliow, by their position, what ther were intended to i they had the effect for which they were designed, and in those castles I sce the type of the fortresses projected br General IInmler. There is one point, I , on which I hare alwars had considerable doubt. I suppose no Officer here 1 will recollect the battles of the MIssore and the irruption of the Maliratt Pindarees down the Western Ghauts into the plains of India, but I hare he men describe the continued terror in which the plain countries were hept days when the Pindarees rode up to the gates of Madras. Where you hare a me range besond which the eje cannot penetrate, where rou hare not the $\mathrm{m}$ acquiring satisfactory headquarter information, rou will be continually rex harassed by the apprehension of what forces of aggression may be coming on and what mar be prepared behind that screen. If, therefore, this plan of barr outlets, which has been adopted particularly in some portions of the Tyrol, a barring of the mountain outlets, I say that will be insufficient. It was rery marked, by a rery distinguished statesman in that last debate, when he suid not only wanted the rectification of frontier, but we wanted to have ejes to ears to hear. One of the great troubles and difficulties of late years has be continual permeation of hostile rumours throngh the defiles, greater or : of tho mountains of Afglianistan. But when the point of obserration is $\mathrm{m}$ into the plain, and represented by the intreneherl camp at Candahar, we to mountnin sereen and see the glacis of the fortress. I quoted on the last $c$ the illustration giren by a German writer, that the north-western frontier wa tress of which the glacis was not in the possession of the garrison. Now know, if our artillery fire is to be worth anthing, we must see the foot of th We see along the reverse of the slope, as considered from the Indian frontit the outlonk or guérite of Candahar, and therefore the occupation of Canda an especial ralue. And it has this especial ralue : it must dram upon it in : the attack of the enemy. Wo wow what is the objectire point of any force from the north-west; and has occurred to me, ou looking at the map double adrantage mas probably be giren by a road marked as abutting on tlu the restward of the line of Kurrichee, that passes through Bela, and gi double access to our natural base, for the natural base of British wa British fortress in communication with the sea, whence nust come ou Woolwich should alwajs be within reach of Furrachee. It is at present. I doubt that the slopes of these hills within the territory of the Khan of Kelat made an additional line of defence; therefore, as a means of keeping the an force within its bonndaries, as a means of secing what is projected bejond of daries by a force that may become agaressire, I cannot but beliere that in plicity this plan deserves most thoroughly the support which I am sur receire from those present, and will command the intelligent apprecintior country.

General Sir Geonge Marcozar: I should be glad to know how we shoulc our Gank if wo took up Candahar as an adraned post, and if it is not necess wo should haro positions in Eastern $A$ fghanistan in order to seeure moral $i$ 
orer its tribes and make them our allies? I foncy that a passire de weakest defence that we can possibly hare. What has been said by Geue suggests to me that we would hare, as it were, half our frontier passive and the other lalf actirely defended. It seems to me that the tribes - Afghanistan could roll domn on our communications between the Bol: dahar if twe did not gain an asecndancy orer them, and I do not think tl defence rould be sufficient either to establish our influence orer tl Afghanistan or to maintain it when it may be established. Perhaps may throw some light on this point in reply to what I hare said.

IInjor-General Sir IExnY Grex : I think that with regard to question of the strategical conditions of our Indian frontier, Gene: lias left me nothing to $8 a y$, I entirely concur with him on erers pu reference to the questions asked by Sir $G$. Malcolm, I should hope th: conclusion of the present campaign we should find ourselres again on fri with the $A$ fghans, in which caso we should not, I consider, require in meddle with Cabul. Ifolding Candahar, as suggested by General Ha narrow strip leading from Quetta to that position, I rould lcaro to the. whole of the rest of their country, interfering with them as little as posis such conditions I should hare no fear for our communications with our o as far as Quctta. They would pass through an entirely friendly State, a Candahar there are no tribes likely to gire trouble under proper ar With regard to the Punjaub frontier we must entirely separate its defer raids of the tribes inhabiting the Sulciman range of mountains, from th of an Army of a powerful European State debouching into the plains to attacking India. To meet the latter contingency General Hamley I construction of strong fortresses at certain strategical points; to meet 1 would suggest the formation of a line of outposts along the whole front close under the mountains connected by a broad, bridged road, and that subjects residing within this line should be disarmed with a ricw to pu to the blood feuds which are carried on between the tribes residing in th and those in the plains, and the continuance of which are one of the lead to mids within British territory, and tend to keep the frontier in $\mathrm{n}$ ce of excitement; but in taling a ray the power of retaliation from our o we must $b_{3}$ prepared to afford them protection, and for this purpose strength of the Punjaub Frontier Force is insufficient and ought to be 12,000 to 20,000 . I would also suggest that erers inducement should the shape of free gifts of land, \&c., to the mountain tribes to sett? families in British territory. Such a plan as that $I$ lare sketched has be found to answer, certainly on a smaller scale, on the Scinde frontier; 1 to hare to deal with hostile tribes aggregating some 170,000 armed men ? ledgo no central authority, and orre allegiance to no one, not eren tribal chiefs, except in a nominal form, is a question extremely difficult I howercr entirely concur with General Iramley that such foes are far front than in our rear, and that to push forward military posts amongst only aggrarate the present unsatisfactory state of affairs. In conelu act that with a British force stationed at Candahar, the Afghans fric Afglian garrison holding IIerat, assisted by a few selected British Oficc contemplate without fear any morements of Russia in Central Asia har objeet an attack upon our Indian Empire.

Major-General Frens : I think, Sir, that the rery interesting lecturc of detenco which we hare heard from DIajor-General Inamles core extent my own feelings and views in this matter, and that this importa Candahar by Ghuznee to Cabul must always remain, in the ejes of mil the chicf strategic line of operation in opposing an enemy coming fro west. I think there can hardls be a difference of opiniou on this approaches and passes there no doubt are, but I feel sure that the - Jighan territories by the Bolan and by Quetta is that which will at most suitable and least open to objection of any kind. General Hamle: o: t the rery superior claims which Candahar has orer any other position rurposes, principally of a defensire character; and in regard to this, I 
there can be two opinions, for when you are at Candahar sou are on th either to Cabul or to IIerat. In regard to the grand ecrics of mountain: between the Dolan Pass and the Suffaed-Kolr Mountains, and again frol to the independent territory of the Kafiristan rallejs, I do think tha change in our policy is desirable. MIs friend Sir IIenry Green, with hi rienee, thinks otherwise; he still approres the policy of holding entirel all the tribes in those mountains, and of degarding them as inpracticabl Tow I cannot but regard with suspicion and dislike a policy which proposc to entertain for these people those undying sentiments of suspicion and tility; I feel compellgal to beliere that an honest desire for their impror command the means of insuring that improrement; and that what $m$ to appal in such an endearour, would with each sueceeding year yicld compulaions of an organization lanring for its ultimate aim their good, : being of their descendants. Whether this task is diffieult or not, I thin be carried out for our own sake, as rell as for the pcople who are our At the close of this present war, Afghanistan must of necessity becom state of the British Empire - a position which we carnot escape from; we like it or not, Afghanistan must eome under cur guardianship and The sooner we recognize this to its full extent, the better for us and for

Lieutenant-Generul OLPrients, V.C.: I am aware that it may appi tuous on my part to adclress such an assembly as this, particularly if should seem to differ from those of such an able authurity on milita General Hamley; and I am also conscions that ererything bearing on aspect of the question before us, wust in this Institution be aroide possible. Nerertheless, when I say that I am no politician, and am party bias, and considering that $I$ am at any rate an older man 1 IIamles, I trust you will grant me your kind indulgence. It is non Jears since I went out to India as a boy-and at that time the first $\mathrm{Af}_{\text {: }}$ going on, and my relative, Sir Willinm MacXanghten, was the Enroy $t h$ he not been killed in time I probabsy should lave been sent up to join have been killed with hin-so that the question of Afghanistan wa pressed on my mind in my younger days, and thet impression has $x$ since. I was also fortunato enough in those diays to encounter men of others one whose name should seud a thrill of emotion through this me of course, Eldred Pottinger, of IIerat celebrity. IIerat wits considerec alwags must be, the hey of India from the north-west; without it proper military posscssion of India. The Hindu Kush is the natural India; its rery name denotes this. No doubt, arrangements, good it may be made of a temporary nature; but, depend upon it, the pr boundary of India, if we are to stop short anywhere in that direction, Iferat and Cabul, by wlich means we slall control Persia on our wes beep Russia at arm's length, and not otherwise. I quite agree with ( in what he says, and $I$ can sce he is of the same mind as $I$ am, onl: does not care to speak as audaciously as $I$ may be doing. I say that, $t$ moment that Russia is to be allowed to descend into the plains a Afghanistan before we meet her, is, to my mind, utterly wrong. W. dream of such a thing. We may hold back from annesing dfghanista the best thing we can do for the Afghans themselves, as for our owr military supreracy in India, is to annex and incorporate that cour Indian Empire. I told a brother of Lord Lawrence, who, I regret, $h$ himsclf to a different opinion, when he asked me what we shou "Afghanistan, and keep it." This I said at the outset of the contr war was declared, and $I$ hare nerer since strersed from that opinion. trars, it grows stronger with me erery day $I$ live. Depend upon it, v the dfglans far better friends of ours if we do so; we shall only irr half measures, such as taking Candahar, and bloching them up in the other passes (on the Frong side, by the way). Are the trikes arou friends of ours? I was with Sir Charles Napier in his hill campaign in also with Sir Ferille Chamberloin, in an expedition against the Wu Kurrum Valley, and likewise with Sir Colin Campbell and Sir Sydney 
Peshawur Valley, and can therefore speat from cxperience of the fronticr tri cannot put your noze safely out of Peshawur in the most peaceful times. I go on for erer in this state? It is intolerable that we should hare to do the only effectual remedy is to "take dfghanistan, and keep it,". when Ind perfectly quiet and tranquil, and the Russian bonndary, if need be, cont with ours. Our true glacis is on the other side of the Hindu Kush dor Oxuz; and anything sliort of that I consider unworthy of the dignity of $t]$ Empire!

In conclusion, I would beg to disclaim any idca of arguing with or pitti against such an able lecturer and strategist as General IIamley, who, if I : to do so, would doubtless soon "turn my flank and stop up my passes!" al trespass too much on your hind consideration, I will now sit down.

General Sir Evwrs Jomssox, R.A.: I have listened with extreme intere: General IIamley has said, and I can only regret thit his obserrations were cxtended, and that he did not go further iuto details. I do not kuoy General Hamley is aware that we hare occupied Peshawur for nearly thi and that we are yet debating what description of fort we ought to er I should like to lhear a description of the nature of the forts and works is he proposes to defend the entrance to the passes, whether they are siu considered with reference to the frontier tribes, or whether he anticipat formidable foe. It would bo adrantageous if Gencral Hamley would $j$ whether his strategical arrangements are designed for the purpose of mo aggressions of our old tribal frontier foes, or whether he has in riew a more formidable eneur. The financial question of our frontier defene scrious one, and our chairman, Sir Ifenry Rawlinson, will bear mo out $v$ that, mainly on financial, though partly on sanitary grounds, we hare $b_{1}$ thirty jears deciding whether wo shall have a fortifed post at Peshaw I should be rery sorry to think that another thirty jears will be spent is what works shall be erected for the security of our rectifed trontier. I p those remarks in hopes that we may hare a little further iuformation on 1 which, howerer, I am quite a ware is a tactical rather than a strategical on

Major-General Hajrex : I thought I had made it quite clear that the w proposed to establish in that place were against the most formidable enemy expect, and that if those works were such as to proride against that en would so much the more provide against any incursions of the hill tribes coneur with all that the different speakers hare said about the policy of the condition of those tribes. It scems to me a positire duty on the country like ours that, when we come in contact with uncirilised people, leare them betier than we find them. But, while strongly of that opinion myself in the present case want to sce the Afghans converted by endir missionaries up the passes. I dare say General Olpherts will creuse 1 adranced stage of the discussion from following hiu into the recesses of Kush. I will only obserte, in reply to him, that the plan I proposel : those works in front of Peshawur at the issue of the path would elose all of the mountains whether in the Hindu Kush or elsewhere, inasmucl passes debouch into the one of which $I$ spoke. As to the nature of th be placed there, which formed the subject of Sir Edwin Johnson's q course, he knows, as well as I do, that it is impossible for anybody not $c$ to tell precisely what description of works would suit the ground; but $w$ what an intrenched camp is, and I hare not the least doubt that there are engincer Olicers now in that country who would in a wesk proride a I would sufficiently answer the purpose. In conclusion, I have only to say $t$ impressed as I aw with the truth of the views I hare cxpressed, it he greatest gratification to me to find them receive the sanction and auth many distinguished Officers.

The Cramaras: With my rers limited practical experience of the a the former Afghan campaign being the only occasion on which I havi actire ecrrice in the field, I feel it would be unbecoming in me to exan detail the professional riews which hare been put forward by General II: which have been generally upprored in the course of the rery instructive 
which has followed. But perhaps I mag be allowed to stato that apr suljject from an entirely different point of view-that is, not exactly fro: but from a general common-sense point of riew-I concur, and concurred, with tlie riews which General Ilamley has expressed. It always been my opinion, since I first turned my attention to the subjec our true policy to look to western Afghanistun, that is to Candahar ruther than to Cabul, and if I may be allowed to read a rerg sliort. what I wrote fourteen years ago, you will see that $I$ then put on rec identical with those that have now been presented to you by General then said, "If Russia should take possession of the Oxus as she has "possession of the Jaxartez, then as her outposts would be in contact "outposts it would become a question for serious consideration whe "Cabul and Ghuznce, the scene of our old disasters, to struggle o " anarchy, it may not be incumbent on us to secure a strong liankin " the occupation of the open country of Quetta and Candahar, and eve I further said, "The time may como when it will be our dut.y to re "Outworks are as necessary to the defence of Empires as of fortrcs " in this riew Herat and Candahar are the Malakoff and Mamelon of "in the East." Now, without troubling you with details, perhaps I ms briefly to state the reasons which led me to that conclusion. Cabul is. awkward a place to hold and to gorern as any city in all dsia. In tl the capital and its neighbourhood are inhabited by a fanatical and disc Jation, incense.l against us by the memorics of the former war, who doubtful obedience eren to Shere Ali himself, and who would, of $\mathrm{cc}$ more unmanageable under any attempt at coercion on our part. I therefore, that it was desirable, if possible, to gire such a place a wi General Hamley has now, I think, rery satisfactorily pointed out that : is possible, since Cabul, if left to itself, can do us no harm, provided that at Candaliar; and that we also sluut up the Khyjber lass so as to close the discontented and hostile spirits at Cabul to emerge upon the ple At Candahar, on the other hand, I desire to impress upon the meetin thing is in our farour. The people in the town and country aroun few instances real Afghans-thes are Parsiwans opposed to the Afgha language, and in religion, and ther have always been most friendly to us again is healthy and agreeable, supplies are abondant, and there soul difficulty, in a military point of riew, in our holding Candahar than is ordinary cantonwent in the l'unjaub or in Scinde. The military positior is, moreover, admimble. General Hamley has already drawn attentio that it intercepts the line of communication between Herat and $\mathrm{Cab}$. much more : in the first place it supports Ilerat in a very effective man posing us to be in possession of Caudahar, with a railroad lidid domn as (and possibly to be continued through the Bolan Pass and on to the Af we should be in a far more efficient position to succour Herat than $\mathrm{Hu}$ in to threaten it from her remote bise on the Caspian or Aral. Agail sion of Cpndahar would render any attnck on India from the IIndu impossible, either by Cabul and the Khyber, or by Ghuznee and Furr position at Candahar rould flank both lines. Another point to be cons Candahar is in the direct line of attack; for if an army erer should from the west or north-west, it would certainly march br the line of Ca? there are no mountains to be erossed, and no physical diffeulties wort] to be encountered, the great line of the Hinda Fush being tur: country being so flat and open that a carriage mas be driven with com IIelmund rirer to Teheran. There is hardly in fact a hill of 100 to 200 on the entire line, and if an inrasion of India is erer to be attempted, tainly therefore be conducted by that route. I fully agree also , Hamley that strong entrenched comps, not of course of the size of that description-not only fortresses, but large intrenched camps capnble of holding a foree of 10,000 or $20,000 \mathrm{men}$; such camps, mouths of the passes would render our position in India perfectly There are two or three smaller questions on which I am not prepares 
give in my adhesion as completely as Gencral Iramley would wish. I th instance, it is still a question whether, putting aside the idea of going as far : interior as Jellalabad or Ghuznec, it still night not be desirable to hold th by a small post at the upper end, as well as the intrenched camp at the lor This is a minor point, $1 \mathrm{know}$, but it is one in which my mind is not satisfied with General Iramley's scheme. 'The holding the Khyber, for inst: a small post at Dacca, as well as by the large camp at the southern cntrance give us a command of the whole length of the pass, which would be invalu the protection of trade and for general passage; whereas, if we only held tl month of the pass, we might be perfectly eafe and strong strategieally, should be neglecting those legitimate calls on our protection which the would seem to require. In the eame way, I should be rery loth to rest Kurrum Yalley to the Afglans. Ilow far the Peiwar Pass can be licld by c at the upher end of the valley I cannot attempt to say, but the ralley certainly a very desirable position, since the inhabitants are friendls and th fertile, and the geographical sit tation is certainly of ralue in enabling us to force within a rery conrenient distance both of Cabul and Ghuznee. Alt] may disagree with General Ilamley on small points of this sort, I am boum that, in regard to the great general question, we should jot attempt to oce whole country of Afghanistan, but should rather block up the eistem de intrenched camps and morely hold the western part of the countrs in strength; on that broad question I am entirely in accord with him. I th hardly worth while to go into the still larger question which has been put: by General Fyers and General Olpherts. To step at once from the plains o to Kafiristan and the line of the Hindu Kush is such an enormous stride in : that it almost takes away one's breath to think of it. We certainly could not that line of frontier and defend it without an enormous inerease to our 1 strength, which would entail extra expense of a million or two millions a si in the present state of the finances of India, I really do not see where the n to como from. I would beg, gentlemen, to remember that in all matters, mil well as political, we hare to regulate our proceedings according to the old. $\mathrm{m}$ "cutting jour coat according to jour cloth." With an imporerished exche canuot branch out into theoretical or sentimental lines of frontier. We occups the line of the IIindu Kush, although upon the map such a fronti appear rery symmetrical and rery desirable, with any ordinary regard resources of India. India cannot afford it, and I am obliged, therefore, to my line of rision to something less ambitious, but more practical, to meas defence less expensive, but, as I beliere, thoroughly sound and scientific, have been trented of by General IIamley. I will only further sas that, w our military netion may be, either in the passes adjoining our frontier. distance in the plains of Candahar, I feel satisfied that our influence : presence may be made most beneficial, not to ourselres only, but to the pe the country. Wherever we have already established posts along the fronties Afghan hills, we have exerted a most civilizing influence on the tribes of the bourhood; and it has often occurred to me, arguing from this experience of years, that if we liad only continued to hare held $\Delta$ fghanistan from the jear 181 we needlessly abandoned the country, and to hare exerted the same hindly be: influence that we hare exerted in the districts below the hills, I beliere the part of $A$ fghanistan at the present day would be as orderly, as quiet, and as 1 ing 2 s the happy prosinces of the Punjaub and Sinde. Remembering what have occurred in the past, it is a pleasing prospect to look forward to somel the same sort in the future. I will, in conclusion, ask jou to pass a rote of to General IIamler.

Lord Ficro: Beforo ne close, I should like to put a question. The ques IIerat has been alluded to in the discussion upon the rers able paper to wi hare listened. General Hamley proposes that the extreme point wo should in this so-called rectification of frontier should be Candahar. General Olphe that Herat was the koy to India, and I beliere Russian opinion is tho same. a correspondent in the East who is in frequent communication with the $R$ and he informs mo that thes speak extremely freely to him upon rarious poil 
that they are umanimous as to the ralue of Herat. They further lau English who are deluded into the belief that they (the Russinns) erentu designs upon India. Ife further says that they look upon it that it mus who can get first to Ilerat. Now we hare lieard; from our Chairman, able paper upon the political aspect of tho question, which is publi Parliamentary papers, contains all tho law and the prophets on this : about the time when that paper was written, he considercl IIerat and 1 the Malakoff and Manclon of India. Nor the Malakoff, we all knor important than the Mamelon, and I should like, as General IIaml occupied the Ifamelon, which is Candahar, to hear from General Rawlins still of the opinion which he expressed, ten or twelre years ago, that it is with a riew to our safety, that we should occupy Herat as that wo she Candahar.

The Criarsras: I purposely aroided touching on the question of 1 in generial terms, on account of the extremo dilliculty of discussing it. General IIamles proposed, or foreshadowed the possibility of, our suppe from Candahar. Candahar is necessarily the first stage of our procee should be almost inclined to sas "Sufficient unto the day is the evil th any rate, we must oceups Candhhar in the first instance. If the necessit it may arisc, $I$ then would venture on a further adrance from Candah but I must be allowed to repent the qualifying clause " if the necessity long as IIerat is not threatened, I think it would be very rash, and in fac offensire, to thrust a force nearly 400 miles in adrance of Candahar, which would cause great additional expensc in kecping up the communi would, moreores, keop us moro or less in hot water with all our neighbo hare no hesitation in saying thai, rather than Russia should occupy Hex imperil the safets of India, in order to gain possession of it. I would the rest of Afghmistan rather than that Herat should be in the hand but so long as it remains in its present condition in the hands of the $\Delta f_{1}$ pendent of Persia and independent of Russia, so long I would not in an fere with it further than by giring it our moral support from our actran at Candahar.

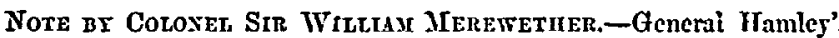
of the ralue of Canclahar to the holders of India is certainly $n$ Candahar is the strategic point. It not only forms the best position to adrance to IIerat when Decessary, and to afford support to th thercof; but no hostile foree could dare to renture on attempt proach to India by Kabool and the Khyber while we hold Candahar Candahar thus held would do awas with the necessity of the pro fort at the mouth (eastern end) of the Khyber Pass. Candahar great adrantages, riz., in facility of communication with its base: it and Quettah the country is easy of transit. There is but one pass, which sappers mould soon make practicable for wheel trafic. The inha always shown themselres most friendly towards $\mathrm{us}$, nnd, we hear, are de Quettah commands all the good roals from Afghanistan to the sea-not by the Bolan, but the others by Kelat and the Moola Pass to Gundara, hill routo through Beloochistan to Soonmcanec and Kurrachec. Our i Belooehistan being now secured, all these roads are perfeetly safe. From Dadur is but 81 miles, of which some 60 are through the defile of the $B$ road for a mountnin pass. Begond Dadur to the sca, a distance of nearl mainly through British territory, is all dead plain. Railway communica exists for more than 300 miles of this distance, from Sulkur on the Indus tc and a fer months more slould see this extended to Dadur. The immedi Caudalar is unquestionably Inurrachee. It is the nenrest and most quic] The connection is complete and safe. All the resourees of the Bombiy with which it is in eass (two and a half days) communication by sen be readily arailed of. And at the same time erery facility exists for ex 
call for the best munitions of war aud reinforements to Woolwich for to the home garricons for the last.

The troop-ships lenring Portsmonth could reach Firrachee in 30 Turmelice is 180 miles nearer Aden than Bombaj is. The harbour at Ku. its improrement, has 29 fect of water on the bar. This will allow of th entering the port at any time during the fair scason-also the trooping October till Miay. Troops and stores would then be placed on the railw: be conrejed to sukkur in tirenty hours. In addition to the railwar, the can be used for the conrejance of stores. There is a flect of steamers . which tors two large cargo barges, and the trip from Kotree to Sukk six to twelve days, according to whether the river is high or low. dificulties in narigating the river in this part. With rail and rirer e transport of stores of all hinds mould be most easy and expeditions. 